IJAMSR 2 (2) www.ijamsr.com CrossRef: https://doi.org/10.31426/ijamsr.2019.2.2.1211

\begin{tabular}{l|l} 
International Journal of \\
I J A M S R
\end{tabular} Advanced Multidisciplinary Scientific Research (IJAMSR) ISSN:2581-4281

\title{
Learning for Making Wayang Kulit in Sanggar Asta Kenya Art
}

\author{
Yogi Laksito Pramono ${ }^{1}$, Suyanto ${ }^{2}$, Adam Wahida ${ }^{3}$ \\ ${ }^{1}$ Postgraduate College Student in Art Education Sebelas Maret University, Surakarta, \\ Indonesia, \\ ${ }^{2,3}$ Lectures in Study Program Art Education Sebelas Maret University, Surakarta, \\ Indonesia
}

Email:yogi_pekinx@yahoo.com

Keywords: Shadow Puppets, Asta Kenya Art Studio.

\begin{abstract}
A B S T R A C T
Wayang kulit (shadow puppets) is one of Indonesia's traditional arts which has many philosophical values and requires particular expertise in making it. The making of wayang kulit must pay attention to the techniques and rules contained in each character in the shadow puppet; this is because each character in the shadow puppet has a form in which there are specific symbolic meanings. Sanggar Asta Kenya Art is a non-formal educational institution that teaches about making puppets to students. Sanggar Asta Kenya Art in the learning process does not only rely on theory, but accompanied by skill practice. The steps taken in learning how to make shadow puppets at the Asta Kenya Art Studio are preparing tools and materials, teaching how to arrange shadowing puppets (forming shadow puppets using tatah tools), menyungging (the process of giving color with color gradation techniques) and exposing creatures (giving paint coatings on wayang kulit). The type of research used is a descriptive qualitative research model in the form of case studies - data collection techniques in the way of interviews, observation and analysis of documents. The results of the study concluded that the Asta Kenya Art Studio applied the conceptual learning of the wayang kulit and proper procedures. In the learning process of making shadow puppets at Sanggar Asta Kenya Art, the teaching role is vital to facilitate the occurrence of learning processes and outcomes in students. Choosing the right strategy and learning model is the key to the success of the teaching and learning process.
\end{abstract}

Citation: Yogi Laksito Pramono, Suyanto, Adam Wahida (2019). Learning for Making Wayang Kulit in Sanggar Asta Kenya Art. International Journal of Advanced Multidisciplinary Scientific Research (IJAMSR ) ISSN:2581-4281, 2 (2), February, 2019, \# Art.1211, pp 1-12 
IJAMSR 2 (2) www.ijamsr.com CrossRef: https://doi.org/10.31426/ijamsr.2019.2.2.1211

\section{Introduction}

The nation of Indonesia is a nation that has a variety of arts. One of them is puppet art, which in 2003 was recognized by the UNESCO world institution as a Masterpiece of the Oral and Intangible Heritage of Humanity. Puppet art has emerged from long ago, and it is unknown who the creator was. According to KRMH. H. Wirastodipuro, BcAP (2006: 430), wayang kulit (shadow Puppets) is an art performance organized by Javanese people and has been going on for hundreds of years. The form of the show is in the way of puppets made from leather (usually buffalo leather), which are exhibited or played by a puppet artist called "dalang" accompanied by traditional Javanese music called "gamelan." Wayang kulit art has experienced various developments, starting from the first time it was called "wayang beber," to changing and experiencing the development of a shadow puppet (purwa) as we see it today. The text of the story that was raised also underwent an event, but some of the stories built in each wayang kulit show still tell a lot about the Mahabharata story diadobsi from the teachings of Hinduism in India.

Wayang kulit is an art that involves many elements, according to S. Haryanto (1988: 2), these elements include "dalang" which acts as a narrative as well as the driver of puppets, accompaniment of traditional Javanese musical instruments, Sinden which accompanies traditional Javanese singing, and equipment other equipment to support the shadow puppet show. In addition to these elements, there are still more actors who play a role behind the success of the shadow puppet show, namely the puppet maker (craftsman). Although his position is not directly involved in the process of a puppet show, his role in the shadow puppet show included in an essential element. Wayang kulit makers (craftsmen) in making works require knowledge and special skills. This is because in making wayang kulit one must pay attention to the rules or rules. One of the studios that teach the making of shadow puppets is the Asta Kenya Art Studio.

Sanggar Asta Kenya Art is an art studio that teaches the making of shadow puppets located in Kepuh Tengah Hamlet Rt 04 Rw 01, Kepuhsari Village, Manyaran District, Wonogiri Regency. Sanggar Asta Kenya Art founded in 2000, found by Retno Larijani. The primary goal is to preserve and develop puppet art especially for the younger generation who are now starting to be less interested in shadow puppet art which they consider challenging to understand and learn. The existence of increasingly developing technology and the 
IJAMSR 2 (2) www.ijamsr.com CrossRef: https://doi.org/10.31426/ijamsr.2019.2.2.1211

increasing influence of western culture has made wayang kulit traditional techniques to eliminated from the attention of the younger generation, especially around the Kepuhsari Village, Manyaran District, Wonogiri Regency. The Manager of Asta Kenya Art Studio is aware of the problems they are facing, but by applying the right learning method of approaching the nation's next generation, eating these problems will gradually be overcome. Start from arguments; this study will explain the learning of wayang kulit at the Asta Kenya Art Studio.

\section{Method}

This research is descriptive qualitative with a multidisciplinary approach, which uses a variety of relevant scientific perspectives and makes direct observations to explore the wayang kulit learning in the Asta Kenya Art Studio. According to Moleong (1991: 3), qualitative research is a form of analysis that produces scientific work using descriptive data in the way of written or oral words from people or behaviors that can observe on the status of groups of people or humans of an object or group culture. The data collection technique used was the observation technique for the Asta Kenya Art Studio location. By looking at teaching and learning activities and conducting interviews with several sources of information (Retno Lawiyani as owner and manager of the studio, Sujoko as Retno Husband and studio manager Lawiyani and Giriyanto as leaders and young mastermind in Kapuhsari Village, Manyaran District, Wonogiri Regency) and conducting analysis from activities carried out by Asta Kenya Art Studio. Data analysis, researchers move in four components, namely data collection, data reduction, data presentation, and drawing conclusions or verification.

\section{Result and Discussion}

Wayang kulit is a traditional art that has long been recognized by the people in Kesari Village, Manyaran District, Wonogiri Regency and has become one of the livelihoods of some villagers. According to Giriyanto (one of the young dalang in Kepuhsari Village) entering the current modern era, puppet art has begun to decline in its development. Many factors have led to a decline in the event of puppet art in Kepuhsari Village, Manyaran District, Wonogiri Regency. One of the facts is due to the lack of interest of the younger generation in traditional wayang kulit art. They consider puppet art as ancient art, and many young people don't want to learn it. Another factor is the place that organizes shadow puppets that 
IJAMSR 2 (2) www.ijamsr.com CrossRef: https://doi.org/10.31426/ijamsr.2019.2.2.1211

\section{International Journal of Advanced Multidisciplinary Scientific Research (IJAMSR) ISSN:2581-4281}

are limited to making wayang kulit art in the Kepuhsari Village area, Manyaran District, Wonogiri Regency increasingly alarming. (Giriyanto, interview, April 8, 2017). Sanggar Asta Kenya Art is one of the studios that cares about the problem. Retno Lawiyani along with Sujoko (her husband) tried to set up a studio that could help the community especially around Kepuhsari Village, Manyaran Subdistrict, Wonogiri Regency to get an education about puppet art (especially in making shadow puppets).

\section{Asta Kenya Art Studio}

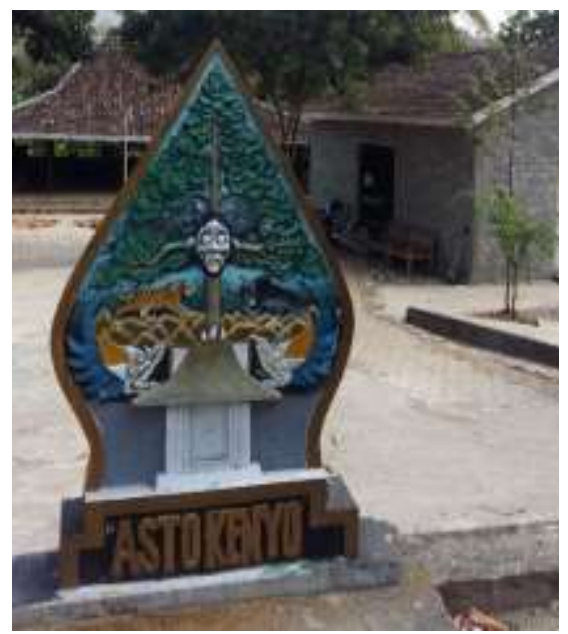

Picture 1.

Photo of Studio Asta Kenya Art (Yogi Laksito Pramono's Documentation, September 8, 2017)

Sanggar Asta Kenya Art is one of the shadow puppet art studios that has produced many wayang kulit makers. According to Retno Lawiyani, the Village of Kepuhsari, especially the Hamlet of Kepuhtengah, has been wellknown for a long time as the center for the making of wayang kulit. This evidence by the number of wayang kulit artisans from the village. (Retno Lawiyani, interview, April 3, 2017).

Retno Lawiyani founded pasta Kenya Art Studio due to her love of puppet art. Retno Lawiyani since childhood has joined various art studios, especially puppet art. From this experience, Retno Lawiyani ventured to establish the Asta Kenya Art Studio.

The Asta Kenya Art Studio has experienced various developments from the beginning of its establishment until now. From the start of the stand, which only had limited facilities and infrastructure (using Retno Lawiyani's private house) until the studio manager could build his teaching and learning site with sufficiently complete facilities and infrastructure. This struggle was carried out by the owner and manager of the Asta Kenya Art Studio using personal funds and also assistance from various parties who care about the development of puppet art, especially in Kepuhsari Village, Manyaran District, Wonogiri Regency. 
IJAMSR 2 (2) www.ijamsr.com CrossRef: https://doi.org/10.31426/ijamsr.2019.2.2.1211

\section{International Journal of Advanced Multidisciplinary Scientific Research (IJAMSR) ISSN:2581-4281}

Sanggar Asta Kenya Art has various teaching and learning activities about the making of wayang kulit. The activity divided into routine and non-routine events. For its regular activities, the Asta Kenya Art Studio organizes a learning process for the making of shadow puppets which are attended by students from various circles who usually start from daytime to nighttime. For non-routine activities, the Asta Kenya Art Studio holds a workshop that is generally often attended by school students or government and private agencies who want to know and learn about making puppets in short.

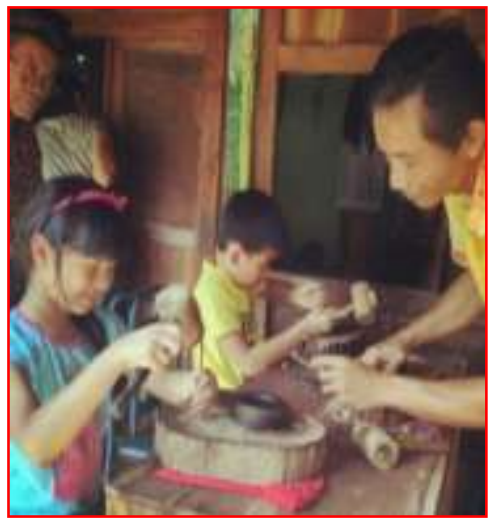

Picture 2

Photo of "Wayang kulit" Learning Activity with Kiara Karitas Elementary School at Asta Kenya Art Studio (Asta Kenya Art Studio Documentation, September 10, 2017)

\section{Puppet Making Learning in Asta Kenya Art Studio}

Asta Kenya Art Studio according to Retno Lawiyani (interview, 10 April 2017), in the learning process there is no time reference. Because the students who study in the studio consist of various ages, and most of them already have their respective activities. Usually, the manager and instructor there divide the learning process time, namely during the day (13.00 WIB to 3:00 p.m. WIB) and at night (7:00 p.m. WIB until 24:00 p.m. WIB). During the day, students who study there are dominated by ages 7 to 16 years. For the night, students who learn more dominated by parents who are married and have a busy day.

The materials and equipment used in the teaching and learning process, the Asta Kenya Art studio always provide equipment and materials for students who want to learn. The studio equipment provides facilities to be used by students even though there is a limited number. As for the materials used in making Retno Lawiyani shadow puppets free all costs to anyone who is inadequate in the procurement and has the desire to learn to make puppets. Because Retno Lawiyani thinks that by eliminating all costs to disadvantaged students, it will lead to the interest of all 
IJAMSR 2 (2) www.ijamsr.com CrossRef: https://doi.org/10.31426/ijamsr.2019.2.2.1211

\section{International Journal of Advanced Multidisciplinary Scientific Research (IJAMSR) ISSN:2581-4281}

residents, especially around Desa Kepuhsari, to learn how to make shadow puppets. (Retno Lawiyani, interview, April 10, 2017). The equipment and materials used in determining how to make shadow puppets used by the Asta Kenya Art Studio are:

\section{a. Providing Raw Materials.}

1) Raw materials provided according to Sujoko (interview, 03 April 2017) include:

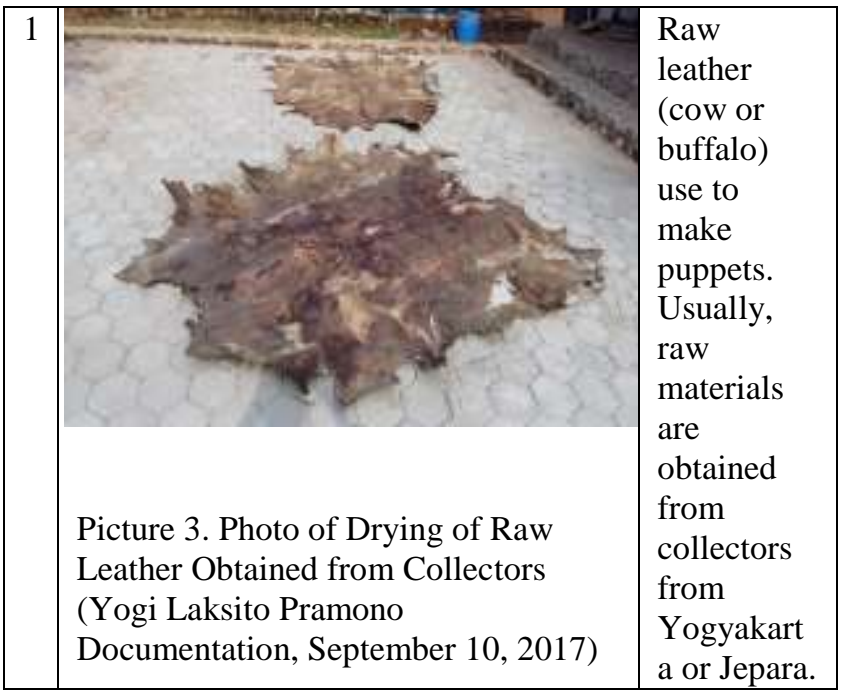

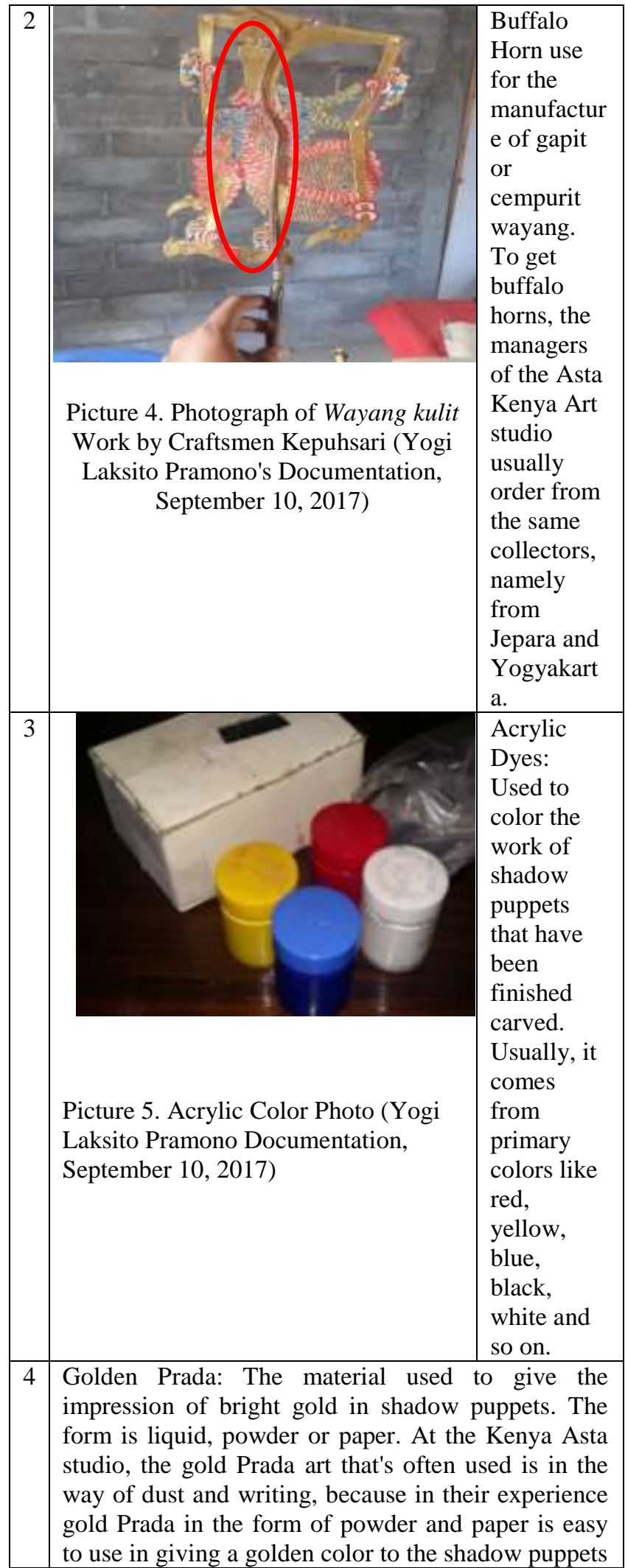


IJAMSR 2 (2) www.ijamsr.com CrossRef: https://doi.org/10.31426/ijamsr.2019.2.2.1211

\section{International Journal of Advanced Multidisciplinary Scientific Research (IJAMSR) ISSN:2581-4281}

b. Has equipment for processing leather.

The equipment used to process raw leather according to Sujoko (interview, April 5, 2017) includes

\begin{tabular}{|c|c|c|}
\hline 1 & $\begin{array}{l}\text { stretching his leather using a nail } \\
\text { (Yogi Laksito Pramono's } \\
\text { documentation, September 10, 2017) }\end{array}$ & $\begin{array}{l}\text { Gawangan: } \\
\text { In the } \\
\text { process of } \\
\text { making } \\
\text { puppets, the } \\
\text { term } \\
\text { gawangan is } \\
\text { a tool used } \\
\text { to stretch the } \\
\text { leather when } \\
\text { cleaning } \\
\text { from fur } \\
\text { impurities } \\
\text { that are still } \\
\text { attached. In } \\
\text { the Asta } \\
\text { Kenya Art } \\
\text { studio, the } \\
\text { gawangan } \\
\text { used is a } \\
\text { large and flat } \\
\text { wood and } \\
\text { how to } \\
\text { stretch the } \\
\text { leather using } \\
\text { nails. }\end{array}$ \\
\hline 2 & \multicolumn{2}{|c|}{$\begin{array}{l}\text { Ax: this tool is usually used to clean the leather from } \\
\text { dirt such as fur, an outer surface and so on. The } \\
\text { process is to scrape the outside of the leather. }\end{array}$} \\
\hline 3 & \multicolumn{2}{|c|}{$\begin{array}{l}\text { Sandpaper: Used to clean the leather after the } \\
\text { cleansing process using axes. According to Sujoko, } \\
\text { usually after the process of cleaning the leather using } \\
\text { a shaft, the surface of the leather still leaves small } \\
\text { impurities that are difficult to lose when cleaned } \\
\text { using axes }\end{array}$} \\
\hline
\end{tabular}

\section{c. Leather-encrusting equipment}

Leather-encrusting equipment according to Sujoko (interview, 5 April 2017), among others:

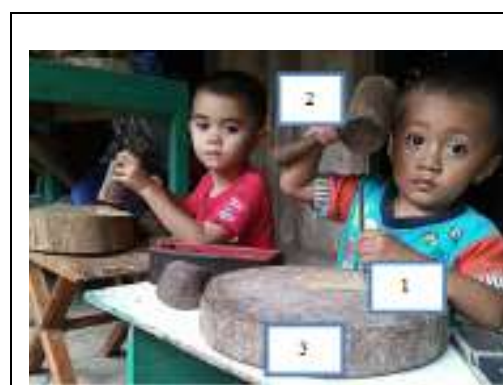

Picture 7. Photos of Students During the Studying Process (Asta Kenya Art Studio Documentation, September 10, 2017)
1 Tatah (various sizes and shapes): Tools that are long in shape, have sharp edges, and are made of steel. This tool serves to puncture the leather and form motifs on the leather.

2 Ganden is a device that shaped like a hammer (a tool for hitting) and made of wood. Ganden used when the hardening process was as a tool in the gaze. The reason why the method of using a garden tool is so that the metal beam is not damaged quickly.

3 Telenan: A tool that is usually circular, has a flat surface, is made of wood, and has a function as a base during the process embedding puppets. The benefit of using Telenan is that the process of arranging creatures is natural and maximized. 
IJAMSR 2 (2) www.ijamsr.com CrossRef: https://doi.org/10.31426/ijamsr.2019.2.2.1211

\section{International Journal of Advanced Multidisciplinary Scientific Research (IJAMSR) ISSN:2581-4281}

\section{d. Coloring equipment.}

The equipment used to dye the leather is using acrylic coloring which is applied using a brush tool. According to Retno Lawiyani (interview, 10 April 2017), the brush tool owned by the Asta Kenya Art Studio varied in size and shape. Usually, in addition to brushing tools, other devices used for coloring are palettes. The purpose of the learning process conducted by Asta Kenya Art Studio according to Retno Lawiyani (interview, 10 April 2017) is to provide additional experience and skills in the field of art to make wayang kulit so that students can use these skills to earn extra income and to preserve shadow puppet art.

This opinion is of the opinion of Marzuki (2010: 140) that non-formal education, such as the studio has the aim of completing public school education by providing extracurricular experiences, artistic activities and so on so that it will be useful to use as a provision in the future. Asta Kenya Art Studio according to Retno Lawiyani (interview, 10 April 2017), using a learning method that is slightly different from formal education. The Asta Kenya Art Studio does not have a curriculum as determined by the government, but has an organized education system with a systematic program as described as follows:

\section{1) First Learning (Introduction to}

\section{Leather and Fine Puppet Art)}

The first lesson is the introduction of Puppet Leather. According to Retno Lawiyani, students who first entered the Asta Kenya Art Studio usually only knew a little about puppet art and had no basis in art. Therefore, educators at the Asta Kenya Art Studio in the first lesson usually introduced first the wayang kulit art from the history, character recognition of the characters contained in wayang kulit, stories raised in the wayang kulit performances and components contained in the performance of wayang kulit. After that, students taught about the basics of fine art in general, namely about the elements of art, the principles of art and colors, all of which learned in Nirmana Dwimatra's subjects. (Retno Lawiyani, interview, April 12, 2017)

\section{2) Second Learning (The process of sketching puppet characters}

After students are considered capable and master basic learning material, according to Retno Lawiyani, students are directed to start sketching out characters in the shadow puppets. (Retno Lawiyani, interview, April 12, 2017). According to Sujoko (interview, 12 April 2017), each character in the shadow puppets 


\section{International Journal of Advanced Multidisciplinary Scientific Research (IJAMSR) ISSN:2581-4281}

has different characters.

\section{3) Third Learning (Arranging Wayang kulit)}

After students get the material for making sketches of the characters of shadow puppets, the following material is an introduction to the techniques of embedding puppets. According to Sujoko, stating puppets is not just about punching and forming shadow puppets. Rather, the artist must understand the characteristics of the puppet character made. In addition to recognizing the characteristics of wayang kulit characters, the skill of arranging shadow puppets is derived from the habit of arranging shadow puppets. The experience gained during the training is what will become the learning capital of students. (Sujoko, interview, April 10, 2017)

According to Retno Lawiyani, leather tatah consists of various forms and types. Each form and type has its character in the gazing. So from that on this material, students are more emphasized on experience in the process by way of practicing directly on the leather. So that students understand faster and have experience in arranging shadow puppets. (Retno Lawiyani, interview, April 10, 2017)
4) Fourth Learning (Giving color to "menyungging" shadow puppets)

After students are considered capable and master the first learning until the third learning, according to Retno Lawiyani students are directed to learn how to color the puppets. giving color to wayang kulit or in Javanese terms called "menyungging" is to apply coloring agents (acrylic coloring) using a brush. In addition to being given a method of sowing, students are also taught the rules in giving wayang kulit. Because shadow puppets have a theory or rule of "grip" in giving color. (Retno Lawiyani, interview, April 10, 2017). According to Sujoko, wayang kulit is an art that has a lot of hidden meaning. These meanings indicated by symbols contained in the characters of each puppet character. Sujoko exemplifies the character of Semar. In the character of the shadow puppet "Semar" used to color the face using white coloring with predetermined attributes. The same thing applies to other puppet figures. (Sujoko, interview, June 10, 2017)

This opinion is in accordance with the theory put forward by Wirastodipuro (2006: 430), shadow puppets made from sheets of leather (Buffalo) which are inlaid, formed and drawn with various colors, which in Javanese tradition 
are called "sungging" and formed in such a way with symbols symbol that resembles its original form. Every character in the shadow puppets made must have their own characters. Therefore, in the process of making wayang kulit, an artist must pay attention to the rules that become a standard for each character from the shadow puppet.

\section{5) Fourth Learning (Learning "Using" shadow puppets)}

According to Retno Lawiyani, the last lesson learned by students is how to "pick up" shadow puppets. Actually, this material is not so difficult to convey to students. Teachers in Studio Asta Kenya Art, usually put more emphasis on how to process buffalo stretchers to be made in the way it kulit puppets and how to install them.

Sanggar Asta Kenya Art is a non-formal educational institution that implements a structured education system and has clear learning goals. Teachers at the Asta Kenya Art Studio apply different learning models in each lesson. Viewed from the pedagogical aspect, the learning process at the Asta Kenya Art Studio can describe as follows:
a) Teacher's master the character of students

The Sanggar Asta Kenya Art teacher in the learning process always researches in advance to the students. Because by knowing and knowing the nature of the students, it is easier for the instructors to deliver the material

b) Teacher's master learning theories and principles of learning in educating

Although the managers and instructors at the Asta Kenya Art Studio do not have an educational background as an educator, with their experiences, the material to be delivered is natural for students to understand
c) Teachers can make learning methods and develop material

Managers and instructors in Sanggar Asta Kenya Art are wayang kulit producing artists who are adept at making shadow puppets. With its ability makes it easy to make learning methods and develop material to be delivered to students.

d) All activities aim to educate students to master the material presented.

The learning model used by the Asta Kenya 
IJAMSR 2 (2) www.ijamsr.com CrossRef: https://doi.org/10.31426/ijamsr.2019.2.2.1211

Art Studio has the aim that students are able and master the material taught. By often carrying out practical activities and producing work, the skills of students are getting better.

\section{Conclusion}

Wayang kulit is a traditional art originating from Indonesia that is obliged to preserve, so that not lost due to the influence of modern culture. The establishment of the Asta Kenya Art Studio is one solution. Wayang kulit art, which has been abandoned by the younger generation by managers of Asta Kenya Art, has been further developed in various ways, one of which is by inviting the younger generation, especially around the Kepuhsari Village area, Manyaran Subdistrict, Wonogiri Regency to learn and use puppet art to become work side.

The process of learning shadow puppets at Sanggar Asta Kenya Art is learning that teaches students how to develop an Indonesian national identity by making shadow puppets by the values contained in wayang kulit and the provisions that apply to make shadow puppets. The learning process of making puppets at Sanggar Asta Kenya Art has a system so arranged that it can influence students and create new experiences for students. This education system is by the theory described by
Atwi Superman (2012: 38), namely a learning process is a system, where the components of learning are interrelated and integrated into a function in achieving a goal, namely to produce qualified or competent graduates such as determined in the learning objectives. The learning components consist of learners, learning processes, expected competency results, instructors, learning materials.

Sanggar Asta Kenya Art has a variety of equipment and facilities that are quite complete to support teaching and learning activities. The learning process of Sanggar Asta Kenya Art also has reasonable procedures to educate students to be able to master the material as the primary goal of learning. The learning process of making puppets in Sanggar Asta Kenya Art, the role of the teacher is essential to facilitate the occurrence of learning processes and outcomes in students. Choosing the right strategy and learning model is the key to the success of the teaching and learning process. The development of teaching and learning activities at the Asta Kenya Art Studio gave birth to puppet artisans. The technological development that is owned by the community makes people more confident with the art of puppets that can be a source of livelihood. Nowadays, there are many wayang kulit artisans in Kepuhsari Village, Manyaran 
IJAMSR 2 (2) www.ijamsr.com CrossRef: https://doi.org/10.31426/ijamsr.2019.2.2.1211

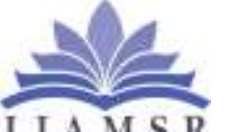

\section{International Journal of \\ Advanced Multidisciplinary Scientific Research (IJAMSR) ISSN:2581-4281}

Subdistrict, Wonogiri Regency who sells their handicraft products by utilizing social media technology.

\section{References}

1) Haryanto, S. 1988. Pratinimba Adhiluhung (Sejarah dan Perkembangan Wayang). Jakarta: IKAPI.

2) Suparman, Atwi. 2012. Desain Instruksional Modern. Jakarta: Erlangga.

3) Marzuki, Saleh H. M. 2010. Pendidikan Nonformal (Dimensi dalam Keaksaraan Fungsional, Pelatihan dan Andragogi). Bandung: Remaja Rosdakarya.

4) Mertosedono, Amir. 1990. Sejarah Wayang: Asal Usul, Jenis dan Cirinya. Semarang: Dahara Prize.

5) Moleong, Lexy J. 1991. Metode Penelitian Kualitatif. Bandung: Remaja Rosdakarya.

6) Murtiyoso, Bambang dkk. 2004. Pertumbuhan dan Perkembangan Seni Pertunjukan Wayang. Surakarta: Citra Etnika.

7) Solichin dan Suyanto. 2014. Cakrawala Wayang Indonesia. Jakarta: Yayasan SENA WANGI.

8) Sri Mulyono. 1982. Wayang: Asal-usul,
Filsafat, dan Masa Depannya. Jakarta: Gunung Agung.

9) Sunarto. 1995. Seni Gatra Wayang kulit Purwa. Yogyakarta: ISI Yogyakarta.

10) Suwarno, Bambang. 2005. Teknik Pembuatan Wayang kulit Gaya Surakarta. Surakarta: STSI Surakarta.

11) Widodo, Marwoto P. 1984. Tuntunan Ketrampilan Tatah Sungging Wayang kulit. Surabaya: V Citra Jaya.

12) Wirastodipuro, KRMH. 2006. Ringgit Wacucal/Wayang kulit/Shadow Puppet. Surakarta: ISI Press Solo.

13) Sumber Online:

14) Johnson David W. and Roger T. Johnson. 2002. Cooperative Learning Methods: A Meta-Analysis. Jurnal of Research in Education. Retrieved on 20 October 2016, from http://www.eeraonline.org/jurnal/files/2 002/JRE_2002_01_DWJohnson.pdf

15) Slamet Subiyantoro, Munawir Yusuf, Hasan Zainnuri. 2016. "Enculturation of Art Value of Carving Decoration (Antropological Studies of Preservation Efforts of Purwo Shadow Puppets in Wonogiri”. Surakarta: Sebelas Maret University. Retrieved on 20 October 2016, from http://jurnal.fkip.uns.ac.id/index.php/ict te/article/view/7569 